\title{
STRATEGI PENGEMBANGAN AGRIBISNIS KOMODITAS PADI DI KABUPATEN KARAWANG PASCA PANDEMI COVID-19
}

\author{
RICE COMMODITY DEVELOPMENT STRATEGY \\ IN KARAWANG DISTRICT POST-COVID-19 PANDEMIC
}

\author{
Dinda Sahara*, Abubakar, Luthfi Nur'azkiya \\ Program Studi Agribisnis Fakultas Pertanian, Universitas Singaperbangsa Karawang \\ Jl. HS Ronggowaluyo, Telukjambe Timur, Kabupaten Karawang, 41361 \\ *E-mail: ndsdin21@gmail.com
}

(Diterima 22-10-2021; Disetujui 15-12-2021)

\begin{abstract}
ABSTRAK
Kabupaten Karawang merupakan salah satu lumbung padi yang ada di Jawa Barat, selain memiliki luas areal pertanian mencapai 94.231 hektar, kabupaten ini juga memberikan kontribusi beras yang di hasilkan Provinsi Jawa Barat. Semenjak tahun 2018 luas panen dan hasil produksi padi di Kabupaten Karawang menurun, diikuti oleh berkurangnya lahan baku sawah setiap tahunnya. Ditambah pandemi Covid-19 yang belum tahu kapan berakhir, berpotensi menganggu ketersediaan dan rantai pasok pangan di Kabupaten Karawang. Permasalahan bertambah kompleks ketika masih belum kuatnya kelembagaan petani, terutama dalam hal manajemen, pengelolaan keuangan, akses pasar, dan rendahnya pendapatan buruh tani. Oleh karena itu, diperlukan suatu strategi untuk mengembangkan agribisnis khususnya pada komoditas padi di Kabupaten Karawang pasca pandemi Covid-19. Penelitian ini bertujuan untuk menganalisis faktor kekuatan, kelemahan, peluang dan ancaman dalam mengembangkan agribisnis komoditas padi, merumuskan alternatif strategi, dan menentukan prioritas strategi yang seharusnya dipilih pemerintah Kabupaten Karawang untuk mengembangkan komoditas padi dalam upaya meningkatkan ketahanan pangan pasca pandemi Covid-19. Jenis penelitian yang digunakan yaitu penelitian deskriptif dengan pendekatan kuantitatif dan kualitatif. Penentuan lokasi penelitian dipilih secara purposive yaitu kecamatan Tempuran, Rawamerta dan Pangkalan. Jumlah sampel yang diambil sebanyak 16 orang. Hasil penelitian menunjukan bahwa dampak pandemi Covid-19 dilihat dari subsistem agribisnis komoditas padi di Kabupaten Karawang yang paling berpengaruh adalah subsistem pendukung (supporting agribusiness) khususnya pada bidang penyuluhan. Analisis QSPM menunjukan bahwa prioritas strategi yang dapat dipilih adalah optimalisasi program pemerintah dalam peningkatan produksi dengan total skor 6.251. Program pemerintah yang perlu dioptimalisasi meliputi intensifikasi yang mencakup sapta usaha tani dan penggunaan teknologi pertanian.
\end{abstract}

Kata kunci: Padi, Strategi Pengembangan, Agribisnis, Karawang, SWOT

\section{ABSTRACT}

The Karawang Regency is one of the rice barns in West Java. Apart from having an agricultural area of 94,231 hectares, this district also contributes to the rice produced by the Province of West Java. Since 2018, the harvested area and yield of rice production in Karawang Regency have decreased, followed by a decrease in raw rice fields every year. Plus, the Covid-19 pandemic, which we do not know when it will end, has the potential to disrupt the availability and supply chain of food in Karawang Regency. The problem becomes more complex when farmers' institutions are still not strong, especially in terms of management, financial management, market access, and the low income of farm workers. Therefore, a strategy is needed to develop agribusiness, especially for rice commodities in Karawang Regency after the Covid-19 pandemic. This study aims to analyze the strengths, weaknesses, opportunities and threats in developing rice commodity agribusiness, formulate alternative strategies, and determine strategic priorities that the Karawang Regency government should choose to develop rice commodities in an effort to 
improve food security after the Covid-19 pandemic. The type of research used is descriptive research with quantitative and qualitative approaches. The location of the research was chosen purposively, namely Tempuran, Rawamerta and Pangkalan districts. The number of samples taken was as many as 16. The results showed that the impact of the Covid-19 pandemic was seen in the rice commodity agribusiness subsystem in Karawang Regency. The most influential was the supporting agribusiness subsystem, especially in the field of extension. QSPM analysis shows that the priority strategy that can be chosen is the optimization of government programs in increasing production with a total score of 6,251. Government programs that need to be optimized include intensification, which includes three farming businesses, and the use of agricultural technology.

Keywords: Paddy, Development Strategy, Agribusiness, Karawang, SWOT

\section{PENDAHULUAN}

Padi sebagai salah satu komoditas tanaman pangan yang hasil produksinya menjadi bahan makanan pokok paling utama bagi sebagian masyarakat di Indonesia masih didominasi oleh sistem budidaya padi sawah. Pertumbuhan jumlah penduduk mendorong meningkatnya kebutuhan manusia yang beranekaragam, salah satunya adalah kebutuhan untuk mencukupi pangan dari beras, oleh karena itu perlu digalakkan usaha peningkatan produksi beras sebagai makanan pokok (Fatma, 2017).

Provinsi Jawa Barat menjadi salah satu lumbung padi utama nasional, karena Jawa Barat menyumbang kurang lebih $17 \%$ dari total produksi padi Indonesia. 942.974 hektar atau 26,48\% total luas wilayah Jawa Barat dialokasikan untuk areal persawahan. Produktivitas padi Kabupaten Karawang sebesar 6 ton per hektar, angka tersebut di atas rata-rata produktivitas padi nasional sebesar 5,2 ton per hektar (Heryawan et al., 2016)

Kabupaten Karawang merupakan salah satu kabupaten yang ada di Provinsi Jawa Barat. Kabupaten ini dikenal masyarakat dengan sebutan kota lumbung padi Jawa Barat karena memberikan kontribusi beras hingga 9\% dari produksi beras yang dihasilkan Provinsi Jawa Barat. Mempunyai luas areal pertanian lahan basah mencapai 94.321 hektar, dan mampu memproduksi padi sekitar 1.485.298 ton GKP per tahun (Viali, 2018).

Letak geografis yang strategis dan memiliki sumber daya pendukung, menjadikan Kabupaten Karawang berkembang dengan pesat. Tumbuhnya Kabupaten Karawang secara umum memberikan tekanan pada aspek lingkungan, kehidupan sosial, ekonomi dan budaya masyarakat. Perkembangan yang sedang dan terus berlangsung ini berpotensi menimbulkan ketidakteraturan 
(Viali, 2018). Menurut data BPS, semenjak tahun 2018 produksi padi di Kabupaten Karawang menurun drastis. Jumlah luas panen pada tahun 2018 sebesar 201.223 hektar tidak sebanding dengan hasil produksinya, yang hanya sebesar 1.124.447 ton GKP. Pada tahun 2019 luas panen menurun menjadi 185.807 ha, dan diikuti oleh turunnya produksi, yang hanya 1.117 .814 ton GKP. Menurut Hasibuan, (2018) total produksi padi di Kabupaten Karawang yang hilang selama enam tahun terakhir adalah sebesar $12.887,97$ ton dan nilai produksi padi yang hilang adalah sebesar 37,56 miliar rupiah.

Penurunan jumlah produksi padi di Kabupaten Karawang diikuti oleh berkurangnya luas baku sawah pada tiap tahunnya. Menurut data Dinas Pertanian Kabupaten Karawang, dalam 8 tahun terakhir luas baku sawah di Kabupaten Karawang berkurang sebanyak 4.064 hektar. Meningkatnya permintaan lahan untuk kegiatan nonpertanian, menyebabkan terjadinya alih fungsi lahan pertanian di Kabupaten Karawang (Wicaksono, 2020). Penurunan luas lahan sawah ini telah mengakibatkan pengurangan kontribusi Kabupaten Karawang untuk ketahanan pangan nasional mencapai 5\% selama 13 tahun terakhir (Rukajat, 2018).

Hal ini tidak sejalan dengan pertambahan penduduk di Kabupaten Karawang, yang menurut data BPS pada tahun 2019 mencapai 2.323,7 ribu jiwa. Bertambahnya jumlah penduduk setiap tahunnya akan berpengaruh pada meningkatnya kebutuhan pangan. Ditambah saat pandemi Covid 19 seperti sekarang yang tidak jelas kapan akan berakhir, berpotensi mengganggu ketersediaan, stabilitas dan rantai pasok pangan di Kabupaten Karawang. Hal yang paling dikhawatirkan jika kondisi ini terus berlangsung adalah terjadinya krisis pangan setelah pandemi Covid 19 ini berakhir.

Permasalahan bertambah kompleks ketika masih belum kuatnya kelembagaan di tingkat petani, terutama dalam hal manajemen, pengelolaan keuangan, akses pasar, dan rendahnya pendapatan buruh tani. Hal ini merupakan salah satu arah pembangunan pertanian yang sebetulnya tertuang pada RPJPD Kabupaten Karawang, yakni: Revitalisasi pertanian dengan sistem agribisnis melalui penguatan kelembagaan petani, penyuluhan dan pelatihan untuk peningkatan kualitas sumber daya 
manusia, pemberian fasilitas sumber pembiayaan/permodalan.

Kabupaten Karawang dihadapkan kepada suatu kompleksitas permasalahan yang saling terkait antar sektor, meskipun demikian cita-cita pembangunan Kabupaten Karawang yang sebagaimana amanat Peraturan Daerah Kabupaten Karawang Nomor 2 Tahun 2010 tentang Rencana Pembangunan Jangka Panjang Daerah (RPJPD) Kabupaten Karawang tahun 2005-2025 yaitu Karawang Sejahtera berbasis pertanian dan industri adalah sebuah tujuan akhir yang harus dicapai menuju kemandirian.

Berdasarkan uraian di atas, maka penelitian ini dilaksanakan dengan tujuan sebagai berikut: mengidentifikasi kekuatan, kelemahan, peluang dan ancaman untuk mengembangkan komoditas padi di Kabupaten Karawang; merumuskan alternatif strategi yang tepat untuk pengembangan komoditas padi dalam upaya meningkatkan ketahanan pangan pasca pandemi Covid 19; menentukan prioritas strategi yang seharusnya dipilih oleh pemerintah Kabupaten Karawang dalam upaya meningkatkan ketahanan pangan pasca pandemi Covid 19.

\section{METODE PENELITIAN}

Lokasi penelitian dilakukan di Kabupaten Karawang, Jawa Barat. Penelitian dilakukan selama 3 bulan sejak bulan Mei - Juli 2021. Metode yang digunakan dalam penelitian ini adalah metode deskriptif analitik. Metode deskriptif analitik yaitu metode penelitian yang menuturkan dan menafsirkan data yang tidak hanya mengumpulkan data dan menyusun data namun meliputi analisis dan arti data tersebut. Data yang dikumpulkan kemudian dijelaskan dan dianalisis. (Rukajat, 2018).

Jenis penelitian yang dilakukan yaitu penelitian deskriptif dengan pendekatan kuantitatif dan kualitatif. Metode penentuan lokasi penelitian dilakukan secara purposive (sengaja) yaitu di Kabupaten Karawang, yakni Kecamatan Pangkalan, Rawamerta, dan Tempuran. Pemilihan daerah penelitian ini dilakukan dengan sengaja (purposive) dengan beberapa pertimbangan. Pertimbangan pertama, didasarkan atas peta Kabupaten Karawang yang terbagi dalam 3 kategori wilayah. Yaitu dataran tinggi, dataran sedang, dan dataran rendah/pesisir. Pertimbangan kedua, 3 kecamatan terpilih merupakan kecamatan yang luas lahan serta produksi padi nya terbanyak dalam 3 tahun terakhir menurut 
data RKSP Dinas Pertanian Karawang (2018-2020). Kecamatan terpilih yaitu Kecamatan Pangkalan untuk mewakili wilayah dataran tinggi, Rawamerta untuk mewakili wilayah dataran sedang, dan Kecamatan Tempuran mewakili wilayah dataran rendah atau pesisir. Tepatnya di Desa Mulangsari Kecamatan Pangkalan, Desa Sukapura Kecamatan Rawamerta, dan Desa Lemahduhur Kecamatan Tempuran. Penentuan lokasi desa ini dilakukan dengan pertimbangan bahwa menurut data UPTD Pengelolaan Pertanian, produksi padi di desa tersebut merupakan yang terbesar pada masingmasing kecamatan. Responden pada penelitian ini dipilih secara purposive yang berjumlah 16 orang yang terdiri atas petani, stakeholder agribisnis komoditas padi seperti dinas pertanian, dinas pangan, dinas perdagangan, bappeda, DPRD Kabupaten Karawang, dan akademisi. Data yang digunakan adalah data primer seperti hasil wawancara dan pengisian kuesioner, dan data sekunder seperti laporan dinas pertanian, BPS, buku, jurnal, serta berbagai literatur dan sumber yang mendukung data penelitian.

Analisis dalam penelitian meliputi analisis faktor internal dan faktor eksternal menggunakan Matriks IFE dan EFE, dilanjutkan dengan analisis matriks
SWOT dan QSPM untuk merumuskan dan menetapkan prioritas strategi. Menurut David (2011), proses penentuan strategi dilakukan melalui tiga tahapan yaitu, tahap pertama pengumpulan data (input stage) tahap input meringkas informasi dasar yang diperlukan untuk merumuskan strategi. Terdiri atas identifikasi faktor-faktor eksternal dan internal dari unit analisis penelitian. Kedua, tahap pencocokan (matching stage), merupakan tahap perumusan alternatif strategi yang menggunakan matriks SWOT. Mencocokan faktorfaktor keberhasilan penting eksternal dan internal merupakan kunci untuk menciptakan alternatif strategi yang masuk akal. Dan yang ketiga tahap pengambilan keputusan (decision stage), pada tahap pencocokan dihasilkan berbagai alternatif strategi yang bisa di tempuh. Setiap strategi tambahan yang dihasilkan dalam tahap pencocokan dapat didiskusikan dan ditambahkan dalam daftar pilihan strategi yang masuk akal. Dengan memeringkat strategi tersebut dalam skala 1 sampai 4 maka daftar prioritas strategi terbaik dapat tercapai. Hal ini dapat dilakukan dengan Matriks Perencanaan Strategis Quantitatif (QSPM). 
HASIL DAN PEMBAHASAN

\section{Identifikasi Faktor Internal dan Eksternal}

Analisis faktor internal dilakukan untuk mengindentifikasi kekuatan dan kelemahan dan analisis faktor eksternal dilakukan untuk mengindentifikasi peluang dan ancaman yang ada sebagai bahan pertimbangan dalam penentuan strategi. Faktor internal dan eksternal dapat dilihat pada Tabel 1 dan 2 .

\section{Dampak Pandemi Covid-19 pada Agribisnis Padi di Kabupaten Karawang}

Sejak pandemi virus Covid-19 mewabah di Indonesia, pemerintah melakukan beberapa kebijakan untuk mengurangi penyebaran virus Covid-19 seperti Pembatasan Sosial Berskala Besar (PSBB), Pelaksanaan Pembatasan Kegiatan Masyarakat (PPKM), PPKM Mikro, PPKM Darurat, dan PPKM 4 Level. Banyak sektor yang terpengaruh karena adanya kebijakan tersebut. salah satunya adalah sektor pertanian khususnya pada komoditas padi. Adapun dampak pandemi Covid-19 dilihat dari subsistem agribisnis komoditas padi di Kabupaten Karawang sebagai berikut:
a. Subsistem Hulu (up-stream agribusiness)
Pada subsistem hulu, menurut petani di Kabupaten Karawang pandemi

Covid-19 tidak memberikan dampak yang signifikan. Karena pada kegiatan pengadaan alat mesin pertanian serta sarana produksi pertanian seperti pupuk, obat-obatan, atau benih dirasa cukup tersedia. Pandemi Covid-19 juga tidak mempengaruhi bantuan alsintan dari pemerintah ke petani yang ada di Kabupaten Karawang, bantuan alsintan tetap tersedia dan tersalurkan dengan baik.

b. Subsistem Usahatani (on-farm agribusiness)

Pada subsistem usahatani, pandemi Covid-19 tidak mempengaruhi petani yang ada di Kabupaten Karawang. karena pada pelaksanaannya petani tetap pergi ke sawah, penerapan social distancing atau protokol kesehatan juga tidak diterapkan pada kegiatan usahatani padi di Kabupaten Karawang.
c. Subsistem Hilir (down-stream agribusiness)

Pada subsistem hilir, pandemi Covid-19 cukup berpengaruh. Pekerja di pabrik penggilingan padi tetap melakukan tugas seperti biasa, tetapi protokol kesehatan seperti penggunaan masker dilakukan di tempat penggilingan, dan disediakan tempat pencucian tangan. Walau tidak dilakukan dengan ketat, 
tetapi ada upaya untuk melakukan protokol kesehatan Covid-19.

d. Subsistem Pemasaran

Pada subsistem pemasaran, pandemi Covid-19 mempengaruhi daya beli masyarakat terhadap beras. Warung nasi serta restoran yang tutup menjadi salah satu faktor yang membuat daya beli menurun. Selain itu, adanya bantuan beras pemerintah juga membuat sebagian masyarakat tidak membeli beras. Ketika diberlakukannya PSBB dan PPKM Level 4 tengkulak dari daerah lain tidak dapat masuk ke desa yang sedang melakukan panen, yang sebenarnya apabila tidak ada tengkulak lokal padi berpotensi menumpuk dan tidak terjual. Tetapi, untuk distribusi tidak berpengaruh walaupun diberlakukan kebijakan PSBB atau PPKM karena sudah ada peraturan pemerintah yang mengatur mengenai distribusi pangan ketika PSBB dan PPKM diberlakukan. Adanya pandemi Covid-19 tidak berpengaruh terhadap harga gabah atau beras.

e. Subsistem Pendukung Agribisnis (supporting agribusiness)

Pandemi Covid-19 sangat mempengaruhi subsistem pendukung agribisnis khususnya pada bidang penyuluhan. Karena dengan adanya pandemi Covid-19 kegiatan penyuluhan terganggu, penyuluh tidak bisa melaksanakan kegiatan penyuluhan masal dan kelompok. Tetapi, sewaktu-waktu penyuluh dapat melakukan penyuluhan secara individu ke rumah anggota kelompok tani. Dengan tidak diadakannya penyuluhan menghambat pemberian informasi mengenai program, bantuan dan inovasi dari penyuluh kepada petani. Maka dari itu, penyuluhan dialihkan menjadi penyuluhan online dengan dibuatnya grup Whatsapp yang nantinya informasi mengenai program, bantuan dan penyuluhan di sebar melalui Whatsapp grup. Tetapi hal ini memiliki hambatan karena tidak semua petani memiliki Whatsapp. Pada subsistem pendukung agribisnis di bidang kegiatan akses pembiayaan seperti Kredit Usaha Rakyat (KUR) dengan Kartu Tani tidak terpengaruh terhadap pandemi Covid-19.

\section{Analisis Matriks Internal Factor Evaluation dan Eksternal Factor Evaluation}

Hasil dari matriks Internal Factor Evaluation (IFE) diperoleh nilai indeks akumulatif untuk elemen kekuatan sebesar 1.55, sedangkan untuk elemen kelemahan diperoleh 0.84 . Hal ini menunjukkan bahwa responden memberikan respon yang tinggi terhadap faktor kekuatan dan respon yang kecil terhadap faktor kelemahan, dengan total 
nilai bobot skor untuk faktor internal secara keseluruhan adalah 2.39. Hasil tersebut menunjukkan bahwa pengembangan agribisnis komoditas padi di Kabupaten Karawang masih di bawah rata-rata dalam kekuatan internal secara keseluruhannya, nilai bobot skor untuk elemen kekuatan lebih besar dibanding bobot skor elemen kelemahan, maka dapat dinyatakan bahwa dalam pengembangan agribisnis komoditas padi di Kabupaten Karawang kekuatan yang dimiliki daerah mampu mengatasi kelemahan yang ada. Namun, hasil skor pembobotan 2.39 (di bawah rata-rata) berarti kondisi pemerintah daerah, dan pelaku agribisnis secara internal (kekuatan dan kelemahan) belum kuat dalam upaya pengembangan agribisnis komoditas padi di Kabupaten Karawang. Analisis faktor kunci internal pada kekuatan dipilih dengan skor tertinggi dan pada faktor kelemahan dipilih dengan skor terendah. Kekuatan utama dalam analisis lingkungan internal agribisnis komoditas padi di Kabupaten Karawang adalah adanya pasar beras karawang dengan skor 0.39. Sedangkan kelemahan utamanya adalah petani tidak dapat menentukan harga dengan skor terendah 0.08 .

Tabel 1. Analisis Matriks IFE

\begin{tabular}{clccc}
\hline No. & Faktor-faktor strategis Internal & Rating & Bobot & Skor Rating x Bobot \\
\hline 1. & Tersedianya input usahatani padi & 3.56 & 0.07 & 0.25 \\
2. & Produktivitas meningkat setiap tahunnya & 3.19 & 0.066 & 0.21 \\
3. & Adanya Pasar Beras Karawang & 3.25 & 0.117 & 0.38 \\
4. & Tersedianya Pabrik Penggilingan Padi & 3.31 & 0.067 & 0.22 \\
5. & Tersedianya KUR & 3.19 & 0.077 & 0.24 \\
6. & Tersedianya Penyuluh Pertanian yang handal & 3.25 & 0.077 & 0.25 \\
\hline & Jumlah Skor Faktor Kekuatan & & & 1.55 \\
\hline & $\quad$ Kelemahan & 1.94 & 0.073 & 0.14 \\
1. & Keterbatasan input saat akan digunakan & 1.81 & 0.069 & 0.13 \\
2. & Produktivitas tidak merata di tiap kecamatan & 1.5 & 0.082 & 0.12 \\
3. & Belum diterapkannya kriteria mutu gabah dan beras & 1.06 & 0.079 & 0.08 \\
4. & Petani tidak dapat menentukan harga & 1.56 & 0.078 & 0.12 \\
5. & Kurangnya akses informasi pasar & 1.63 & 0.077 & 0.13 \\
6. & Tidak meratanya adopsi teknologi & 1.69 & 0.069 & 0.12 \\
7. & Tidak semua petani memiliki akses KUR yang & & 0.84 \\
\hline & berintegrasi dengan kartu tani & & 1 & 2.39 \\
\hline
\end{tabular}

Sumber : Analisis Data Primer (2021) 
Tabel 2. Analisis Matriks EFE

\begin{tabular}{|c|c|c|c|c|}
\hline No. & Faktor-faktor strategis Eksternal & Rating & Bobot & Skor Rating x Bobot \\
\hline \multicolumn{5}{|c|}{ Peluang } \\
\hline 1. & Tersedianya bantuan input & 3.44 & 0.076 & 0.26 \\
\hline 2. & $\begin{array}{l}\text { Adanya program pemerintah dalam peningkatan } \\
\text { produksi }\end{array}$ & 2.88 & 0.078 & 0.23 \\
\hline 3. & $\begin{array}{l}\text { Adanya inovasi pengolahan beras menjadi produk } \\
\text { jadi }\end{array}$ & 1.69 & 0.071 & 0.12 \\
\hline 4. & Menjalin kemitraan pemasaran hasil pertanian & 2.56 & 0.08 & 0.21 \\
\hline 5. & Penyuluh tersedia dengan gelar sarjana & 3.31 & 0.071 & 0.23 \\
\hline 6. & Adanya asuransi agribisnis & 2.56 & 0.061 & 0.16 \\
\hline \multicolumn{4}{|c|}{ Jumlah Skor Faktor Kekuatan } & 1.2 \\
\hline \multicolumn{5}{|c|}{ Ancaman } \\
\hline 1. & Naiknya harga input & 2 & 0.078 & 0.16 \\
\hline 2. & Alih fungsi lahan & 2.13 & 0.069 & 0.15 \\
\hline 3. & Adanya serangan hama & 2.25 & 0.072 & 0.16 \\
\hline 4. & Perubahan cuaca ekstrem yang tidak menentu & 2 & 0.072 & 0.14 \\
\hline 5. & Terbukanya keran impor beras & 1.06 & 0.085 & 0.09 \\
\hline 6. & Penjadwalan penyuluhan tidak teratur & 3.19 & 0.063 & 0.2 \\
\hline 7. & Tidak ada dana alat peraga penyuluhan & 3.31 & 0.064 & 0.21 \\
\hline 8. & Bunga pinjaman tinggi & 3.56 & 0.06 & 0.21 \\
\hline \multicolumn{4}{|c|}{ Jumlah Skor Faktor Kelemahan } & 1.33 \\
\hline & Jumlah Skor Faktor Eksternal & & 1 & 2.53 \\
\hline
\end{tabular}

Sumber : Analisis Data Primer (2021)

Hasil analisis matriks Eksternal Factor Evaluation (EFE) untuk elemen peluang diperoleh nilai indeks kumulatif 1.2, sedangkan nilai bobot skor elemen ancaman sebesar 1.33. Hal ini menunjukkan bahwa responden memberikan respon yang cukup tinggi terhadap faktor ancaman dan respon yang lebih kecil terhadap faktor peluang. Total nilai bobot skor untuk faktor eksternal secara keseluruhan adalah 2.53, ada di skor rata-rata yang berarti Kabupaten Karawang sudah cukup memanfaatkan peluang untuk menghindari ancaman dalam mengembangkan agribisnis komoditas padi. Peluang utama dalam analisis lingkungan eksternal agribisnis komoditas padi di Kabupaten Karawang ditunjukkan oleh faktor peluang dengan nilai tertimbang tertinggi yaitu tersedianya bantuan input dengan skor 0.26 dengan rata-rata bobot 0.076 dan rata-rata rating 3.44. Nilai skor tertinggi pada faktor peluang sebesar 0.26 menunjukkan pemerintah pusat maupun pemerintah daerah Kabupaten Karawang merespon baik penyediaan bantuan input kepada pelaku agribisnis khususnya petani yang ada di Kabupaten Karawang. Sedangkan ancaman utama ditunjukkan 
oleh faktor ancaman dengan nilai tertimbang terendah adalah terbukanya keran impor beras dengan skor sebesar 0.09 dengan rata-rata bobot 0.085 dan rata-rata rating sebesar 1.06. Nilai skor terendah pada faktor ancaman sebesar 0.09 menunjukkan bahwa terbukanya keran impor beras sangat menjadi ancaman bagi pelaku agribisnis khususnya petani yang ada di Kabupaten Karawang, karena apabila dilakukan impor beras, terlebih ketika panen raya, akan terjadi keanjlokan harga gabah di tingkat petani, selain itu juga beras yang dibeli petani berpotensi tertumpuk di gudang penggilingan karena tidak terserap oleh pasar, yang pada akhirnya akan berpengaruh kepada kesejahteraan para petani yang ada di Kabupaten Karawang.

\section{Analisis SWOT}

Menurut David (2011), matriks SWOT adalah sebuah alat pencocokan yang penting yang membantu para manajer mengembangkan empat jenis strategi, yaitu (1) strategi SO (kekuatanpeluang). Strategi ini dibuat berdasarkan jalan pikiran perusahaan, yaitu dengan memanfaatkan seluruh kekuatan untuk merebut dan memanfaaatkan seluruh kekuatan untuk merebut dan memanfaatkan peluang sebesar-besarnya, (2) strategi WO (kelemahan-peluang). Strategi ini diterapkan berdasarkan pemanfaatan peluang yang ada dengan cara meminimalkan kelemahan yang ada, (3) Strategi ST (kekuatan-ancaman). Strategi dalam menggunakan kekuatan yang dimiliki perusahaan untuk mengatasi ancaman, dan (4) Strategi WT (kelemahan-ancaman). Strategi ini didasarkan pada kegiatan yang bersifat defensif dan berusaha meminimalkan kelemahan yang ada serta menghindari ancaman. Mencocokan faktor-faktor eksternal dan internal utama merupakan bagian tersulit dalam mengembangkan matriks SWOT dan membutuhkan penilaian yang baik dan tidak ada satu pun paduan yang paling benar. 
Tabel 3. Penentuan Alternatif Strategi dengan Analisis SWOT

\begin{tabular}{|c|c|c|}
\hline IFE & STRENGTHS (S) & WEAKNESSES (W) \\
\hline EFE & $\begin{array}{l}\text { Tersedianya input usahatani padi } \\
\text { Produktivitas meningkat setiap } \\
\text { tahunnya } \\
\text { Adanya Pasar Beras Karawang } \\
\text { Tersedianya Pabrik Penggilingan Padi } \\
\text { Tersedianya KUR } \\
\text { Tersedianya Penyuluh Pertanian yang } \\
\text { handal }\end{array}$ & $\begin{array}{l}\text { Keterbatasan input saat akan } \\
\text { digunakan } \\
\text { Produktivitas tidak merata di } \\
\text { tiap kecamatan } \\
\text { Belum diterapkannya kriteria } \\
\text { mutu gabah dan beras } \\
\text { Petani tidak dapat menentukan } \\
\text { harga } \\
\text { Kurangnya akses informasi pasar } \\
\text { Tidak meratanya adopsi } \\
\text { teknologi } \\
\text { Tidak semua petani memiliki } \\
\text { akses KUR yang berintegrasi } \\
\text { dengan kartu tani. }\end{array}$ \\
\hline OPPORTUNITIES (O) & STRATEGI SO & STRATEGI WO \\
\hline $\begin{array}{l}\text { Tersedianya bantuan input } \\
\text { Adanya program pemerintah } \\
\text { dalam peningkatan produksi } \\
\text { Adanya inovasi pengolahan } \\
\text { beras menjadi produk jadi } \\
\text { Menjalin kemitraan pemasaran } \\
\text { hasil pertanian } \\
\text { Penyuluh tersedia dengan gelar } \\
\text { sarjana } \\
\text { Adanya asuransi agribisnis } \\
\end{array}$ & $\begin{array}{l}\text { Optimalisasi program pemerintah } \\
\text { dalam peningkatan produksi (S1,S2,S5, } \\
\mathrm{O} 1, \mathrm{O} 2, \mathrm{O} 6) \\
\text { Membuat sentra agribisnis perberasan } \\
\text { pada kawasan sentra padi } \\
(\mathrm{S} 1, \mathrm{~S} 2, \mathrm{~S} 3, \mathrm{~S} 4, \mathrm{~S} 5, \mathrm{~S} 6, \\
\mathrm{O} 1, \mathrm{O} 2, \mathrm{O} 3, \mathrm{O} 4, \mathrm{O} 5, \mathrm{O} 6) \\
\text { Membuka agrowisata Padi Kabupaten } \\
\text { Karawang (S5,S6,O5) }\end{array}$ & $\begin{array}{l}\text { Membangun industri padi yg } \\
\text { berkualitas (W3,W4, O4, O5) } \\
\text { Optimalisasi peran penyuluh } \\
\text { pertanian. } \\
\text { (W1,W2,W3,W4,W5,W6, W7, } \\
\text { O5) }\end{array}$ \\
\hline THREATS (T) & STRATEGI ST & STRATEGI WT \\
\hline $\begin{array}{l}\text { Naiknya harga input } \\
\text { Alih fungsi lahan } \\
\text { Adanya serangan hama } \\
\text { Perubahan cuaca ekstrem yang } \\
\text { tidak menentu } \\
\text { Terbukanya keran impor beras } \\
\text { Penjadwalan penyuluhan tidak } \\
\text { teratur } \\
\text { Tidak ada dana alat peraga } \\
\text { penyuluhan } \\
\text { Bunga pinjaman tinggi }\end{array}$ & $\begin{array}{l}\text { Membuat BUMD di sektor pangan } \\
(\mathrm{S} 2, \mathrm{~S} 3, \mathrm{~T} 5, \mathrm{~T} 8) \\
\text { Optimalisasi penerapan regulasi (S6, } \\
\mathrm{T} 2, \mathrm{~T} 5, \mathrm{~T} 6)\end{array}$ & $\begin{array}{l}\text { Subsidi Harga (W4, T1,T4,T5) } \\
\text { Membuat kawasan pertanian } \\
\text { berbasis korporasi petani (W1, } \\
\text { W3, W4, W5, W6, T1, T2, T3, } \\
\text { T4,T6,T7,T8) }\end{array}$ \\
\hline
\end{tabular}

Sumber: Analisis Data Primer (2021)

\section{Analisis Matriks QSP}

Dari hasil analisis matriks SWOT telah diperoleh sembilan alternatif strategi yang bisa diterapkan untuk pengembangan agribisnis komoditas padi di Kabupaten Karawang. Untuk menentukan prioritas strategi yang paling tepat dan utama maka dilakukan analisis QSPM (Quantitatif Strategic Planning
Matriks) untuk pengambilan keputusan. QSPM dapat memberikan gambaran kelebihan-kelebihan relatif dari masingmasing strategi yang selanjutnya memberikan dasar objektif untuk dapat memilih salah satu atau beberapa strategi spesifik yang menjadi pilihan. Dari ke sembilan strategi maka terpilih lima statregi yang dapat diimplementasikan. 
Hasil QSPM menunjukkan bahwa strategi yang menjadi prioritas utama dengan Sum Total Attractiveness Score (STAS) sebesar 6.251 adalah strategi "Optimalisasi program pemerintah dalam peningkatan produksi” .Kemudian strategi yang memiliik nilai STAS terkecil adalah strategi "Membuat BUMD Sektor Pangan" dengan nilai sebesar 4.044 Prioritas strategi disusun berdasarkan urutan nilai STAS tertinggi sampai terendah. Adapun prioritas strategi yang dihasilkan matriks QSP dapat dilihat pada Tabel 4.

Tabel 4. Analisis QSPM

\begin{tabular}{clc}
\hline No & \multicolumn{1}{c}{ Strategi } & Nilai STAS \\
\hline 1 & Optimalisasi program pemerintah dalam peningkatan produksi & 6.251 \\
2 & Optimalisasi peran penyuluh & 6.202 \\
3 & Membuat sentra agribisnis perberasan pada kawasan sentra padi & 6.031 \\
4 & Membangun industri yang berkualitas & 5.409 \\
5 & Membuat BUMD sektor pangan & 4.044 \\
\hline
\end{tabular}

Sumber : Analisis Data Primer (2021)

\section{KESIMPULAN DAN SARAN}

Kesimpulan

Dampak pandemi Covid-19 dilihat dari subsistem agribisnis komoditas padi di Kabupaten Karawang yang paling berpengaruh adalah subsistem pendukung (supporting agribusiness) khususnya pada bidang penyuluhan. Karena dengan adanya pandemi Covid-19 kegiatan penyuluhan terganggu, penyuluh tidak bisa melaksanakan kegiatan penyuluhan masal dan kelompok. Tetapi, sewaktuwaktu penyuluh melakukan penyuluhan secara individu ke rumah anggota poktan. Dengan tidak diadakannya penyuluhan menghambat pemberian informasi mengenai program, bantuan dan inovasi dari penyuluh kepada petani. Maka dari itu, penyuluhan dialihkan menjadi penyuluhan online dengan dibuatnya grup Whatsapp dan nantinya informasi mengenai program, bantuan dan penyuluhan di sebar melalui Whatsapp grup. Tetapi hal ini memiliki hambatan karena, tidak semua petani memiliki Whatsapp. Adapun prioritas strategi pengembangan agribisnis komoditas padi di Kabupaten Karawang pasca pandemi Covid-19 sebagai berikut: Optimalisasi program pemerintah dalam peningkatan produksi (STAS: 6.251), Optimalisasi peran penyuluh (STAS: 6.202), Membuat sentra agribisnis perberasan pada kawasan sentra padi (STAS: 6.031), Membangun industri yang berkualitas (STAS: 5.409), Membuat BUMD sektor 
pangan (STAS: 4.044). Strategi prioritas utama yang dapat diimplementasikan oleh pelaku agribisnis di Kabupaten Karawang dipilih berdasarkan hasil Sum Total Attractiveness Score (STAS) tertinggi adalah Optimalisasi program pemerintah dalam peningkatan produksi (STAS : 6.251).

\section{Saran}

$\begin{array}{ccc}\text { Program } & \text { pemerintah dalam } \\ \text { peningkatan } & \text { produksi padi perlu }\end{array}$ dioptimalisasi karena belum semua petani melaksanakannya. Program pemerintah yang perlu dioptimalisasi meliputi intensifikasi yang mencakup sapta usahatani dan penggunaan teknologi pertanian. Sapta usahatani tersebut meliputi pengolahan tanah yang baik, pengairan/irigasi yang teratur, pemilihan bibit unggul, pemupukan yang tepat, pengendalian hama dan penyakit secara terpadu, penanganan pasca panen yang effisien dan pemasaran (Aji et al., 2014).

\section{UCAPAN TERIMA KASIH}

Penulis berterimakasih pada seluruh responden penelitian yakni bapak Muhrodi Suhrozi, bapak Edi Suryana, bapak Admin, bapak Ilman Nur Syamsudin, bapak Hari Ahmad, bapak Asep, bapak Udin, bapak Wahyu, bapak
Nanang F., bapak Dedi Sudrajat, bapak Professor Kadi Pirngadi, ibu Suhaeni, bapak Acim Mulyana, bapak Rustam, bapak Irvan, bapak Udoy, dan bapak Anam yang telah bersedia membantu penulis mendapatkan data yang sebenarnya.

\section{DAFTAR PUSTAKA}

Aji, A. A., Satria, A., \& Hariono, B. (2014). Strategi Pengembangan Agribisnis Komoditas Padi Dalam Meningkatkan Ketahanan Pangan Kabupaten Jember. Jurnal Manajemen Dan Agribisnis, 11(1), 60-67.

David, F. R. (2011). Manajemen Strategis: Konsep-konsep. Salemba Empat.

Fatma, A. U. (2017). Analisis Penerapan Sistem Agribisnis Terhadap Produksi dan Pendapatan Pada Usahatani Padi di Kecamatan Purwodadi Kabupaten Grobogan. Universitas Diponegoro.

Hasibuan, A. S. (2018). Analisis faktorfaktor yang mempengaruhi konversi lahan pertanian sawah ke non pertanian di Kabupaten Karawang. Sekolah Pascasarjana Institut Pertanian Bogor.

Heryawan, A., Fauzi, A., \& Hidayat, A. (2016). Analisis Ekonomi Dan Kebijakan Sumber Daya Alam Provinsi Jawa Barat. Journal of Agriculture, Resource and Environmental Economics, 1(2), 111.

Rukajat, A. (2018). Pendekatan Penelitian Kuantitatif. Deepublish.

Viali, G. (2018). Strategi Pemerintah Daerah Dalam Mempertahankan Karawang Sebagai Lumbung Padi Tahun 2016 Studi Pada Dinas 
Pertanian Kabupaten Karawang. Universitas Padjajaran.

Wicaksono, A. (2020). Implementasi Program Lahan Pertanian Pangan Berkelanjutan (LP2B) Kabupaten Karawang: Studi Kasus Penetapan Luas Baku Sawah. Jejaring Administrasi Publik, 12(9), 89-107. 